\title{
Renal effects of uroguanylin and guanylin in vivo
}

S.L. Carrithers ${ }^{1}$, M.J. Hill1, B.R. Johnson ${ }^{1}$, S.M. O' $\mathrm{H}^{2} \mathrm{ara}^{1}$, B.A. Jackson², C.E. Ott², J. Lorenz' ${ }^{3}$, E.A. Mann³, R.A. Giannella ${ }^{3}$, L.R. Forte ${ }^{4}$ and R.N. Greenberg ${ }^{1}$

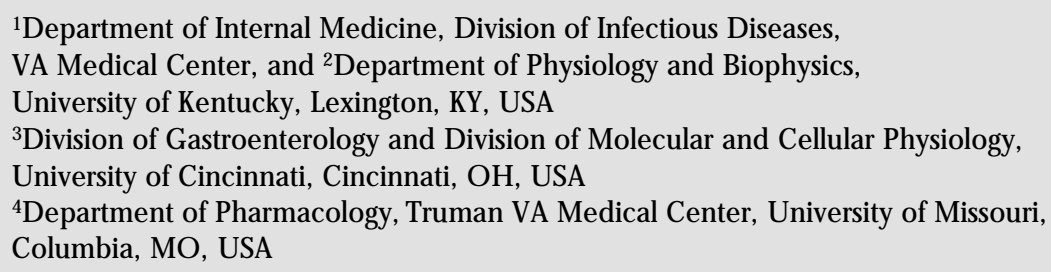

\section{Correspondence}

R.N. Greenberg

Department of Internal Medicine

Division of Infectious Diseases

University of Kentucky

VA Medical Center

800 Rose Street, UKM C-M N 668-A

Lexington, KY 40536-0084

USA

Fax: + 1-606-323-1020

E-mail: rngree01@ pop.uky.edu

Presented at the M eeting

"NO Brazil, Basic and Clinical

Aspects of Nitric O xide",

Foz do Iguaçu, PR, Brazil,

March 10-13, 1999.

Received May 28, 1999

Accepted July 8, 1999

\section{Abstract}

Uroguanylin and guanylin are newly discovered endogenous heatstable peptides that bind to and activate a membrane bound guanylyl cyclase signaling receptor (termed guanylyl cyclase C; GC-C). These peptides are not only found in blood but are secreted into the lumen of the intestine and effect a net secretion of electrolytes $\left(\mathrm{Na}^{+}, \mathrm{K}^{+}\right.$, $\mathrm{Cl}^{-}, \mathrm{HCO}_{3}^{-}$) and fluid into the intestine via a cyclic guanosine-3',5'monophosphate (cGMP) mechanism. GC-C is also the receptor for Escherichia coli heat-stable enterotoxin (STa) and activation by STa results in a diarrheal illness. Employing mouse renal in vivo models, we have demonstrated that uroguanylin, guanylin, and STa elicit natriuretic, kaliuretic, and diuretic effects. These biological responses are time- and dose-dependent. Maximum natriuretic and kaliuretic effects are observed within 30-40 min following infusion with pharmacological doses of the peptides in a sealed-urethra mouse model. Our mouse renal clearance model confirms these results and shows significant natriuresis following a constant infusion of uroguanylin for $30 \mathrm{~min}$, while the glomerular filtration rate, plasma creatinine, urine osmolality, heart rate, and blood pressure remain constant. These data suggest the peptides act through tubular transport mechanisms. Consistent with a tubular mechanism, messenger RNA-differential display PCR of kidney RNA extracted from vehicle- and uroguanylintreated mice show the message for the $\mathrm{Na}^{+} / \mathrm{K}^{+}$ATPase $\gamma$-subunit is down-regulated. Interestingly, GC-C knockout mice (Gucy2c-/-) also exhibit significant uroguanylin-induced natriuresis and kaliuresis in vivo, suggesting the presence of an alternate receptor signaling mechanism in the kidney. Thus, uroguanylin and guanylin seem to serve as intestinal and renal natriuretic peptide-hormones influencing salt and water transport in the kidney through GC-C dependent and independent pathways. Furthermore, our recent clinical probe study has revealed a 70-fold increase in levels of urinary uroguanylin in patients with congestive heart failure. In conclusion, our studies support the concept that uroguanylin and guanylin are endogenous effector peptides involved in regulating body salt and water homeostasis.

\section{Key words}

- Guanylyl cyclase C

- Heat-stable enterotoxin

- Kidney

- Natriuresis

- Sodium-potassium ATPase

- Differential display PCR 


\section{Introduction}

A considerable body of evidence supports a role for the guanylyl cyclase C (GCC)-cyclic guanosine-3',5'-monophosphate (cGMP) pathway in the control of fluid and electrolyte transport in mammals (1). Early studies on the mechanism of action of the Escherichia coli heat-stable enterotoxin (STa), which are secreted by enteric bacteria and cause travelers diarrhea, demonstrated its signal transduction to be initiated by GC$\mathrm{C}$ (1). However, the STa/GC-C ligand receptor axis has been shown to utilize an endogenous pathway utilizing cell-specific secretion of STa-like mimic peptides involving the intestine and other organs (2). Uroguanylin and guanylin, two newly identified endogenous peptides of 13-15 amino acids, were shown to bind to and activate GC-C in the intestinal mucosa and cause significant elevation of intracellular cGMP resulting in increased $\mathrm{Cl}^{-}$secretion from the gut $(3,4)$.

Our objective was to assess the role of uroguanylin and guanylin, which we have recently shown to increase cGMP accumulation in the intestinal and renal epithelium $(5,6)$. Uroguanylin and guanylin are initially expressed as inactive propeptides. Subsequent activation of the active peptide forms is accomplished by cleavage and release of the $\mathrm{COOH}$-terminal amino acid moieties (2). Biologically inactive (prohormone form) and active moieties of uroguanylin and guanylin circulate in the plasma of mammals, suggesting an endocrine mechanism for their action in addition to the autocrine and paracrine fashion in which they have been shown to act in the intestine $(2,7)$.

Most of the research to date has been involved in the characterization of the uroguanylin and guanylin signaling pathway in the intestine. However, due to the role that these peptides play in electrolyte and water homeostasis, the kidney should be investigated. The overall goal of the studies outlined in this report was to test the fundamen- tal hypothesis that uroguanylin and guanylin act as natriuretic and diuretic peptide hormones which act on the kidney to regulate sodium homeostasis during normal salt intake and disorders involved in imbalances of fluid and electrolytes. Our studies will focus on the biological actions of uroguanylin and guanylin on renal function employing an in vivo sealed or catheterized urethra mouse model. These experiments are followed by a study measuring the urinary uroguanylin levels in patients with congestive heart failure, a disorder characterized by sodium retention and fluid overload with resulting pulmonary and peripheral congestion.

\section{Experimental procedures}

\section{Suckling mouse intestinal fluid assay}

Uroguanylin, guanylin, and STa were tested for their ability to induce intestinal fluid accumulation in newborn mice as described previously (5). ICR-Harlan SpragueDawley (HSD) suckling mice 2-4 days old were dosed per os with $0.1 \mathrm{ml}$ of test solution. The injections contained vehicle (HEPES) alone or the peptides with and without the protease inhibitors chymostatin (0.1 mmol) and aprotinin (0.67 units). After administration of vehicle or peptide agonists, the mice were kept at room temperature for $3 \mathrm{~h}$. The mice were then killed, intestinal and body weights measured, and a ratio of the intestinal weight to remaining body weight was calculated. A ratio of 0.0875 represents one mouse unit of activity. The secretion activity (one unit) of STa was 3.75 $\mathrm{ng} /$ mouse (5); uroguanylin was $41.5 \mathrm{ng} /$ mouse, and guanylin was $142.9 \mathrm{ng} /$ mouse.

\section{The sealed-mouse renal function assay}

Six-week-old male ICR/HSD mice (Harlan; colony bred), weighing 18-25 g were used in the sealed-mouse renal function assay (5). Each mouse was exposed to 
methoxyflurane in a desiccator until the mouse was unconscious. At this time, the abdominal region was shaved and a 25 -gauge needle was inserted through the skin to the visible bladder. Urine was aspirated and the bladder emptied. The urethra was cannulated by PE- 5 tubing or sealed shut with Krazy glue and the mouse was placed in a restrainer to limit excessive movement. Fifty microliters of test solution $(0.2 \%$ Evan's blue dye (indicator for intravenous injection) with or without peptide) was injected into the tail vein. After the indicated time, the animal was again exposed to methoxyflurane, the bladder contents emptied, and the urine volume recorded. The mouse was then sacrificed by open chest pneumothorax. Urine sodium, potassium, and osmolality were measured. Sodium and potassium levels were determined by flame photometry (Instrumentation Laboratory Autocal Flame Photometer model 643, Lexington, MA, USA) and osmolality was measured by an osmometer (Wescor 5100B Vapor Pressure Osmometer, Logan, UT, USA). Osmolality was not reported because the values did not differ significantly. Prior to the experiment, the mice were allowed to drink ad libitum. Their diet had consisted of $18 \%$ crude protein, $9 \%$ crude fat, $4 \%$ crude fiber, and $11 \%$ crude moisture (Prolab Rat, Mouse, Hamster 2000, Harlan, Indianapolis, IN, USA).

\section{Cyclic GMP accumulation assay in T84 cells}

The detection and quantification of uroguanylin extracted from urine samples was performed using a de novo T84 cell stimulation bioassay by previously described methods (8). T84 cells were grown as monolayers in 24-well plates as described previously (9). The bioactivity, which is represented as pmol cGMP produced $\min ^{-1} \mathrm{ml}^{-1}$, was a direct measure of the amount of GC-C stimulating peptide present in a particular sample. Uroguanylin bioactivity was assessed at acidic $\mathrm{pH}(5.5)$ (8). Briefly, the sample was layered onto the T84 cell monolayers for $40 \mathrm{~min}$ at $37^{\circ} \mathrm{C}$. The media was removed, and the cells were washed twice with serum-free media. Cells were lysed and peptide-induced cGMP was measured using a specific RIA ( $\alpha$-cGMP antibody was kindly provided by Donald C. Robertson, Ph.D., University of Idaho, Moscow, ID, USA), and protein was measured (BioRad, Hercules, CA, USA) using bovine serum albumin as standard. The effects observed on cGMP accumulation in this assay under acidic conditions reflect primarily, if not completely, the bioactivity of uroguanylin in the urine. The effects of other known urine peptides were compared with those of synthetic uroguanylin and guanylin. Under acidic conditions employed in this bioassay, guanylin, the other known endogenous GC$\mathrm{C}$ activating peptide, is approximately 150 times less potent than uroguanylin. Sensitivity for this bioassay approaches 1 pmol cGMP well $^{-1} \mathrm{mg}$ protein ${ }^{-1}$, which is similar to the sensitivity found previously $(4,8)$. Peptides of the atrial natriuretic peptide (ANP) family $\left(10^{-6} \mathrm{M}\right.$; ANP, brain natriuretic peptide (BNP), C-type natriuretic peptide (CNP), urodilatin) do not stimulate increases in intracellular cGMP in this assay, nor does sodium nitroprusside $\left(10^{-3} \mathrm{M}\right)$ or urinary cGMP (since it is removed during the preparative Sep-Pak step) $(3,4,10)$.

\section{Messenger RNA differential display PCR}

Differential display (11) was performed on 100 ng of normalized DNase-treated RNA in a $20-\mu 1$ reverse transcription reaction containing $50 \mathrm{mM}$ Tris- $\mathrm{HCl}, \mathrm{pH} 8.3,75 \mathrm{mM}$ $\mathrm{KCl}, 3 \mathrm{mM} \mathrm{MgCl}_{2}, 10 \mathrm{mM} \mathrm{DTT}, 20 \mu \mathrm{M}$ each $\mathrm{dNTP}, 2.5 \mu \mathrm{M}$ anchored primer, and $15 \mathrm{U} / \mu \mathrm{l}$ MMLV reverse transcriptase (Life Technologies, Gaithersburg, MD, USA). Anchored primers were a series of three 21 -mers, each with an EcoRI restriction site, $\mathrm{T}_{11}$ stretch and a single $3^{\prime}$ base, either $\mathrm{G}$, A, or $\mathrm{C}$. The reaction was incubated $60 \mathrm{~min}$ at $37^{\circ} \mathrm{C}$ and then for $5 \mathrm{~min}$ at $95^{\circ} \mathrm{C}$, followed by a $4^{\circ} \mathrm{C}$ 
hold. Utilizing a GeneAmp PCR kit (PerkinElmer, Norwalk, CT, USA), 20- $\mu 1$ PCR reactions, with $2 \mu$ of the reverse transcriptase reaction as template, were prepared in duplicate containing $10 \mathrm{mM}$ Tris- $\mathrm{HCl}, \mathrm{pH} 8.3,50$ $\mathrm{mM} \mathrm{KCl}, 1.5 \mathrm{mM} \mathrm{MgCl} 2,0.001 \%$ gelatin, $20 \mu \mathrm{M}$ each dNTP, $1 \mu \mathrm{M}$ anchored primer, 1 $\mu \mathrm{M}$ arbitrary decamer-primer (GEP Services, Oklahoma City, OK, USA), $12.5 \mu \mathrm{Ci}(1 \mathrm{Ci}=$ $37 \mathrm{GBq}){ }^{35}$ S-dATP (DuPont/NEN, Wilmington, DE, USA), and $0.5 \mathrm{U}$ of AmpliTaq per reaction. Ten different arbitrary primers were employed in PCR. Following an initial 60-s denaturation step at $95^{\circ} \mathrm{C}$, thermal cycling consisted of: $94^{\circ} \mathrm{C}, 30 \mathrm{~s} ; 40^{\circ} \mathrm{C}, 120 \mathrm{~s} ; 72^{\circ} \mathrm{C}$, $30 \mathrm{~s} ; 40$ cycles. A final extension of cDNA at $72^{\circ} \mathrm{C}$ for 5 min completed PCR cycling, which was followed by a $4^{\circ} \mathrm{C}$ hold. Amplified samples were subjected to electrophoresis under denaturing conditions using acrylamide (6\%)/urea (40\%) DNA sequencing gels prepared with $1 \mathrm{x}$ TBE buffer $(89 \mathrm{mM}$ Tris base, $89 \mathrm{mM}$ boric acid, $2 \mathrm{mM}$ EDTA, $\mathrm{pH}$ 8.0). Five microliters of formamide loading dye $(95 \%$ formamide, $20 \mathrm{mM}$ EDTA, $0.05 \%$ bromophenol blue, $0.05 \%$ xylene cyanol, $\mathrm{pH}$ 8.0) was added to each $20 \mu \mathrm{l}$

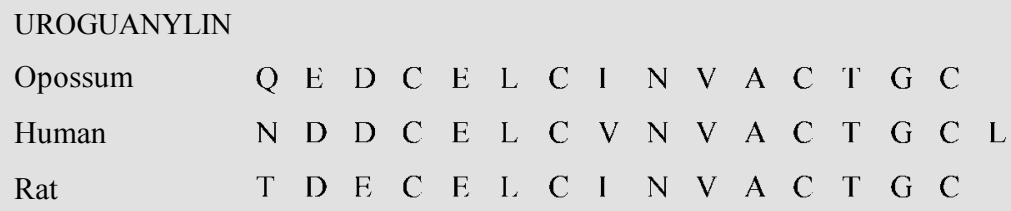

\section{GUANYLIN}

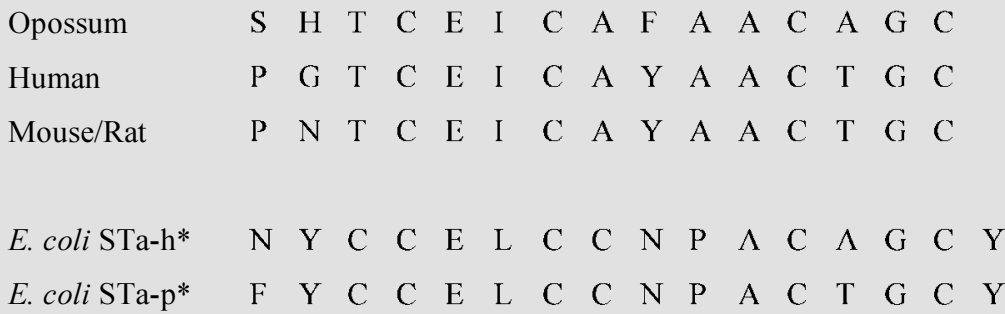

Figure 1 - Primary structures of uroguanylin, guanylin, and the Escherichia coli heat-stable enterotoxin (STa). *Not shown are additional amino acid residues on the amino-terminus of STa that are "N-S-S" for STa-h (isolated originally from human) and " $\mathrm{H}-\mathrm{T}$ " for STa-p (isolated originally from swine). sample, then heat-denatured at $90^{\circ} \mathrm{C}$ for 5 min before loading $8 \mu \mathrm{l}$ per well with duplicate reactions. The gels were run at $85 \mathrm{~W}$ for $4 \mathrm{~h}$, dried onto Whatman 3-mm paper, and exposed to X-ray film for $2-4$ days at $-70^{\circ} \mathrm{C}$. The cDNA bands that were visually selected for sub-cloning showed a difference in the display pattern between the Ugn-treated and vehicle (saline)-treated mice. Luminescent paint dots were used to align the autoradiogram and gel, and only the single most intense center band of a multiple band series was excised from the dried gel. This excised band with attached Whatman paper was rehydrated in $100 \mu \mathrm{l}$ of water and eluted at room temperature for $10 \mathrm{~min}$ followed by $100^{\circ} \mathrm{C}$ for $15 \mathrm{~min}$. After cooling, the paper and gel pieces were removed and DNA was precipitated, washed in ethanol, and resuspended in $\mathrm{H}_{2} \mathrm{O}$. The band was amplified by PCR again, and an aliquot was analyzed on a $1.5 \%$ agarose gel to confirm amplification of the cDNA band of interest. The product was ligated into the pNoT7 shuttle vector (5 Prime-3 Prime, Inc., Boulder, CO, USA) for sequencing, which was performed by the University of Kentucky Sequencing Core Facility.

\section{Results}

Uroguanylin and guanylin are endogenous heat-stable peptides of 13-15 amino acids containing 2 disulfide bonds that are mimicked by STa in primary and secondary structures (Figure 1). Figure 1 shows the primary structures of STa, uroguanylin, and guanylin. Both uroguanylin and guanylin are intestinal peptides that activate guanylyl cyclase molecules on the luminal surface of the intestinal epithelium. We assessed the potency of uroguanylin and guanylin with the suckling mouse intestinal fluid assay. Figure 2 demonstrates that uroguanylin is more potent in causing intestinal secretion of fluid than guanylin, but neither peptide is as potent in the diarrheal response as STa: 
guanylin, $142.9 \mathrm{ng} /$ mouse $<$ uroguanylin, $41.5 \mathrm{ng} /$ mouse $<\mathrm{STa}, 3.75 \mathrm{ng} /$ mouse (5). This assay was employed with these peptides because we needed a quantitative assessment of both uroguanylin and guanylin before in vivo and in vitro renal function assays could be performed.

To address the question whether uroguanylin and guanylin affect renal function in vivo, experiments were designed to measure the urine output, sodium and potassium excretion, and urine osmolality after intravenous injections of the agonist-peptides. We also asked the question if these effects mediated by uroguanylin and guanylin occurred in a time-dependent and dose-response manner. The sealed-mouse renal function assay was employed to test these questions. Figure 3 (left panels) demonstrates that both uroguanylin and guanylin caused an increase in urine volume, and total urinary sodium and potassium excretion in a time-dependent fashion when compared to control (vehicle)-injected mice. The urine osmolalities did not change (data not shown). Eighty minutes post-injection showed the highest significant increase in urine volume for both the uroguanylin- and guanylin-stimulated responses to exogenous peptide treatment. Also, uroguanylin was more active in the in vivo renal function assay that guanylin (even when the guanylin injection solution contained the protective protease inhibitor cocktail of chymostatin and aprotinin) (5). This pattern was shown to be consistent in the natriuretic and kaliuretic effects mediated by uroguanylin and guanylin. A dose-response for diuresis, natriuresis, and kaliuresis was also observed for uroguanylin and guanylin (Figure 3, right panels). As previously demonstrated in the time course for the renal effects of uroguanylin and guanylin, uroguanylin elicited a greater natriuresis than guanylin. Maximal diuresis, natriuresis, and kaliuresis were observed at 80 min post-injection with approximately 10-30 units of peptide.
To examine the molecular events induced by uroguanylin during the sealed-urethra mouse renal function assay, we employed differential display PCR of RNA from treated and control mice (Figure 4). Control mice were treated with an intravenous injection of vehicle only, whereas the experimental mice were treated with bioactive uroguanylin (10 units of peptide (as quantitated by the suckling mouse assay) for $80 \mathrm{~min}$ ). An increase in urine volume, and total urinary sodium and potassium was observed for two mice. The kidneys were removed for RNA immediately following the assay endpoint. Reverse transcription followed by PCR and electrophoresis demonstrated that multiple amplified products are up- or down-regulated. The arrow shown in Figure 4 is the PCR-amplified product that we chose to expand upon. This down-regulated DNA was cut out of the gel, subcloned, and sequenced. The protein translated from this gene was the $\mathrm{Na}^{+} / \mathrm{K}^{+}$ATPase $\gamma$-subunit. We suggest that uroguanylin treatment $i v$ induces a downregulation of the gene that constitutes one of the major protein sodium pumps in the nephron.

To determine if the effects of uroguanylin in the kidney are mediated by its receptor, GC-C, we employed the sealed-mouse renal function assay on GC-C deficient mice (12). These transgenic mice were developed to test for the impact of GC-C mediated events in the mammal. Using an optimum time and concentration of uroguanylin in the assay,

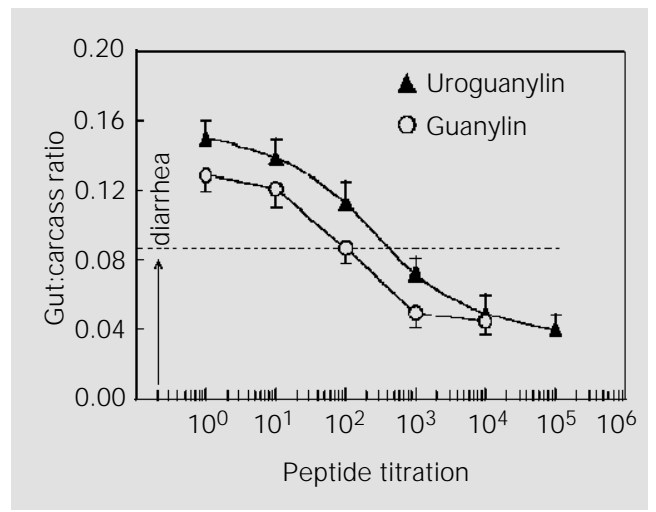

Figure 2 - Assessment of potency for uroguanylin and guanylin employing the suckling mouse intestinal fluid assay. Uroguanylin (triangles) and guanylin (circles) were serially diluted before a 0.1-ml solution in HEPES was injected into suckling mice ( $N=4-6$ mice per dose). Diarrhea is assessed as the gut/carcass ratio over 0.0875 (dashed line). Results are reported as the mean \pm SEM. 

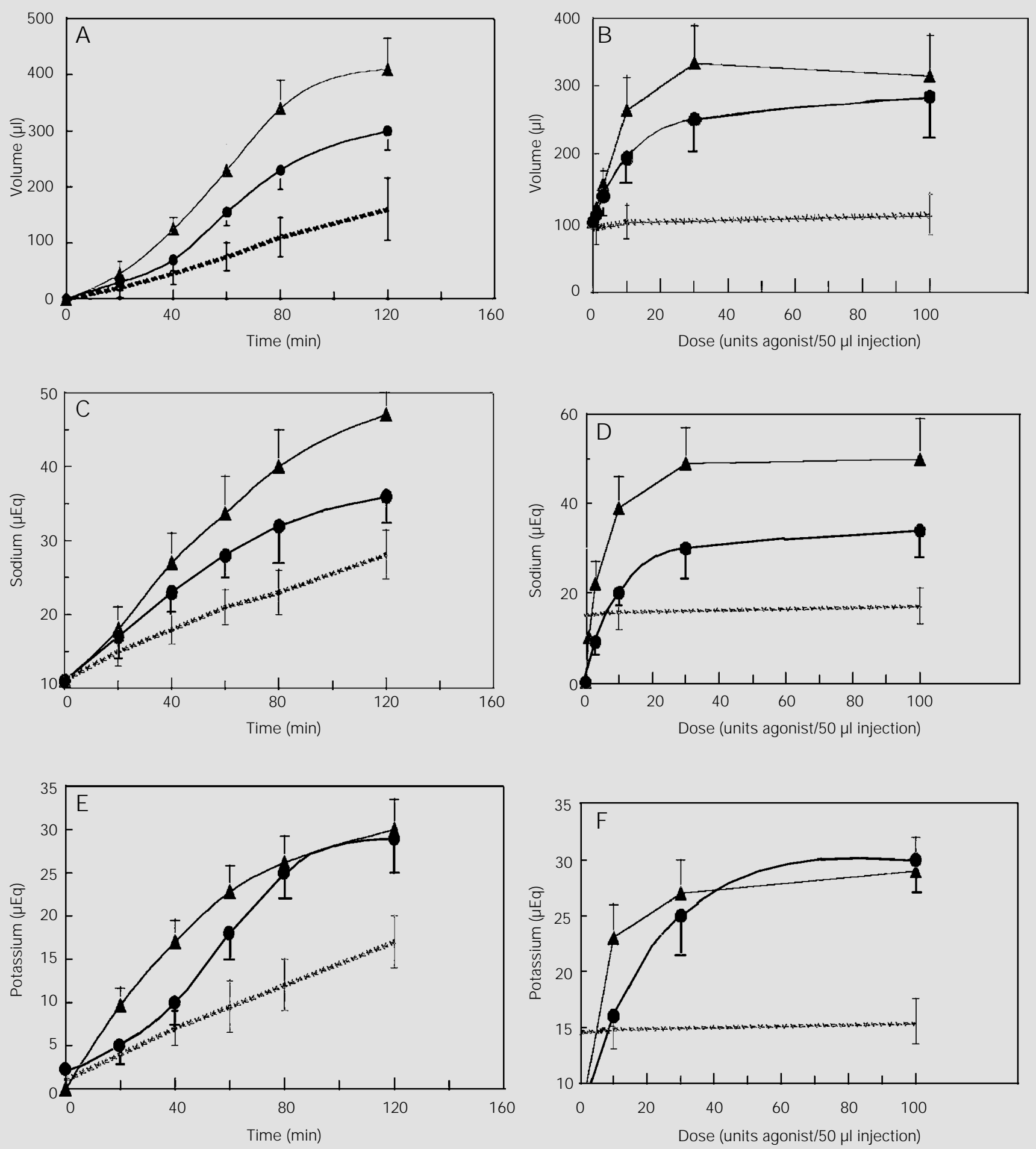

Figure 3 - Uroguanylin and guanylin elicit a time-dependent (using 10 units peptide) and dose-dependent (using 80 min) increase in urine volume, and total urinary sodium and potassium in the sealed-mouse renal function assay. Panels A, B, Increase in diuresis with 10 units of uroguanylin and guanylin; Panels C, D, increase in natriuresis; Panels E, F, increase in kaliuresis. Uroguanylin (triangles), guanylin (circles), control (dotted lines). Data points are represented as the mean \pm SEM of six or more mice. 
GC-C null mice responded to exogenous uroguanylin in a similar fashion to normal wildtype mice (Table 1). The osmolalities for each animal are similar. These data suggest that in the kidney, uroguanylin, and possibly guanylin, are mediated by a GC-C independent mechanism.

\section{Discussion}

Uroguanylin and guanylin are two newly identified intestinal peptides that cause $\mathrm{Cl}^{-}$ secretion into the lumen of the gut via cGMP mechanisms. We tested the hypothesis that due to their secretagogue nature both peptides should influence renal function. We tested our hypothesis employing an in vivo model; the sealed-mouse renal function assay. Through comparing the effects of urinary fluid volume and increased sodium and potassium levels in the urine of vehicle shaminjected mice to agonist-treated mice, one can obtain information about the renal function of a peptide-agonist. We demonstrated that both uroguanylin and guanylin induce diuresis, natriuresis, and kaliuresis in vivo in a time- and dose-dependent fashion. Uroguanylin is more active in causing a natriuretic effect in our model. However, guanylin appears to have as much of an effect on kaliuresis as uroguanylin, suggesting that guanylin could act through a different mechanism of action than uroguanylin.

Differential display RT-PCR of the RNA extracted from the kidneys of the sealedmouse assay show that the $\gamma$-subunit of $\mathrm{Na}^{+} /$ $\mathrm{K}^{+}$ATPase is down-regulated by uroguanylin treatment. It is not known if down-regulation of the $\gamma$-subunit influences reabsorption of sodium in the nephron. However, inhibition of the channel protein does result in a loss of reabsorbed sodium by the kidney. Thus, further studies are required in order to determine a direct role for uroguanylin and the $\mathrm{Na}^{+} / \mathrm{K}^{+}$ATPase.

Lastly, uroguanylin must exert its effects through a GC-C independent fashion in the

\begin{tabular}{l|rrrr} 
& C-1 & Ugn-1 & C-2 & Ugn-2 \\
\hline Urine volume & $150 \mu \mathrm{l}$ & $550 \mu \mathrm{l}$ & $220 \mu \mathrm{l}$ & $610 \mu \mathrm{l}$ \\
$\mathrm{Na}^{+}, \mathrm{mEq}$ & 17055 & 55000 & 27158 & 71736 \\
$\mathrm{~K}^{+}, \mathrm{mEq}$ & 12210 & 45595 & 22440 & 91317 \\
Osmolality, mOsm/kg & 1083 & 976 & 1020 & 1309 \\
\hline
\end{tabular}

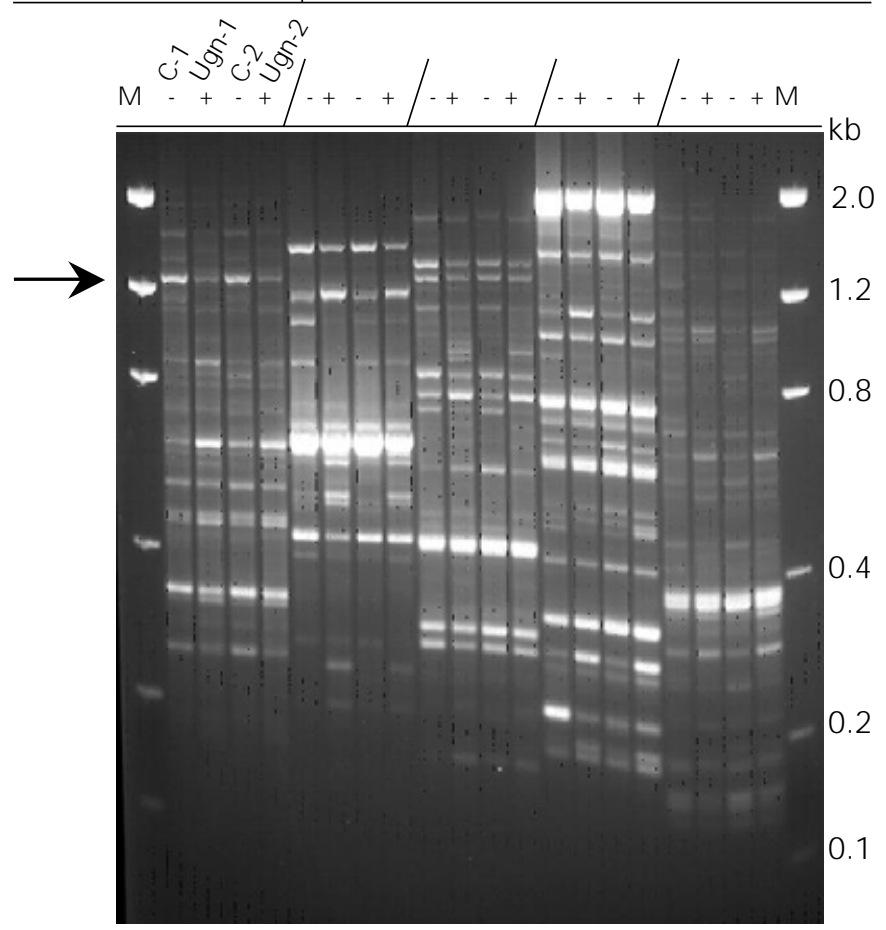

Figure 4 - Messenger RNA differential display profile of mouse kidney treated with and without uroguanylin. A sealed-mouse renal function assay $(80 \mathrm{~min})$ was performed in duplicate with injections containing vehicle with and without 10 units of uroguanylin. The table (above the autoradiogram) shows the raw data (total volume, sodium, and potassium) from this particular experiment employing the sealed-mouse renal function assay. C-1, C-2 are control-vehicle-treated mice and Ugn-1, Ugn-2 are mice treated with uroguanylin. The slash mark separates the series of samples, which are in the order of C-1, Ugn-1, C-2, Ugn2. " - " and " + " indicate which mice were treated without and with uroguanylin. Differential display was performed according to the Methods section. M, Size markers in kilobases (kb). The arrow indicates the excised band in lane 1 that was amplified, sequenced, and shown to be a message for the mouse $\mathrm{Na}^{+} / \mathrm{K}^{+}$ATPase $\gamma$-subunit.

Table 1 - GC-C null mice respond to exogenous uroguanylin.

Thirty units of uroguanylin (Ugn) was administered iv to mice through the tail vein. After $60 \mathrm{~min}$, the urine from the animal was removed and analyzed for sodium, potassium, and osmolality. Gucy2c (-/-) mice represent the GC-C knockout mice and the wildtype $(+/+)$ strain is homogenous for the GC-C gene and contains GC-C (12).

\begin{tabular}{lcccccc}
\hline Strain & Treatment & $\begin{array}{c}\text { Urine volume } \\
(\mu \mathrm{l})\end{array}$ & $\begin{array}{c}\text { Sodium } \\
(\mu \mathrm{Eq} / \mathrm{ml})\end{array}$ & $\begin{array}{c}\text { Potassium } \\
(\mu \mathrm{Eq} / \mathrm{ml})\end{array}$ & $\begin{array}{c}\text { Osmolality } \\
(\mathrm{mOsm} / \mathrm{kg})\end{array}$ & $\mathrm{N}$ \\
\hline Gucy2c $-/-$ & Control & 133 & 10083 & 19406 & 924 & 3 \\
& + Ugn & 210 & 38278 & 38664 & 991 & 4 \\
Wildtype $+/+$ & Control & 110 & 21155 & 11643 & 848 & 4 \\
& + Ugn & 236 & 46926 & 27656 & 816 & 4 \\
ICR/HSD & Control & 138 & 27750 & 18152 & 855 & 12 \\
& + Ugn & 202 & 32829 & 26053 & 927 & 12
\end{tabular}


kidneys of the GC-C null mice. The receptor for uroguanylin could be another isoform of GC-C. It would follow that another receptor for the uroguanylin/guanylin family of receptors exists due to the fact that there are multiple receptors for the atriopeptins (guanylyl cyclase $\mathrm{A}$, guanylyl cyclase $\mathrm{B}$, and the natriuretic peptide receptor C). Recently, another GC-C isoform has been cloned from opossum kidney distinct from GC-C (13). However, it has yet to be defined that this particular GC-C isoform is present in nonmarsupial mammals. Secondly, it has yet to be determined that this isoform of GC-C exists in the intestine of opossum, since intestinal GC-C has not been cloned from this animal.

In conclusion, uroguanylin and guanylin are intestinal (and possibly renal) peptides that may play a role in fluid and electrolyte balance. Exogenous uroguanylin and guany- lin increase sodium and potassium excretion in a time- and dose-dependent fashion. Their mechanism(s) of action in the kidney may be both GC-C dependent and independent due to the fact that the $\mathrm{GC}-\mathrm{C}$ null mice respond to uroguanylin with a significant diuresis, natriuresis, and kaliuresis. Uroguanylin causes a series of molecular changes in the renal RNA expression pattern that may or may not contribute to alterations in sodium excretion. Thus, in order to attribute a more direct role for the physiological function of uroguanylin and guanylin peptides on renal function, mouse renal clearance studies need to be performed. Our laboratory has successfully set up these models and thus, we will be able to investigate various questions as to whether these peptide-induced effects on the kidney proceed through hemodynamic and/or tubular transport mechanisms.

\section{References}

1. Field M, Graf J r LH, Laird WJ \& Smith PL (1978). Heat-stable enterotoxin of Escherichia coli: In vitro effects on guanylate cyclase activity, cyclic GMP concentration, and ion transport in small intestine. Proceedings of the National Academy of Sciences, USA, 75: 2800-2804.

2. Forte LR \& Hamra FK (1996). Guanylin and uroguanylin: intestinal peptide hormones that regulate epithelial transport. News in Physiological Sciences, 11: 1724

3. Currie MG, Fok KF, Kato J, Moore RJ, Hamra FK, Duffin KL \& Smith CE (1992). Guanylin: an endogenous activator of intestinal guanylate cyclase. Proceedings of the National Academy of Sciences, USA, 89: 947-951.

4. Kita T, Smith CE, Fok KF, Duffin KL, Moore WM, Karabotsos PJ , Kachur J F, Hamra FK, Pidhorodeckyj NV, Forte LR \& Currie MG (1994). Characterization of human uroguanylin: A member of the guanylin peptide family. American J ournal of Physiology, 266: F342-F348.

5. Greenberg RN, Hill M, Crytzer J, Krause WJ , Eber SL, Hamra FK \& Forte LR (1997).
Comparison of effects of uroguanylin, guanylin, and Escherichia coli heat-stable enterotoxin STa in mouse intestine and kidney: evidence that uroguanylin is an intestinal natriuretic hormone. J ournal of Investigative Medicine, 45: 276-283.

6. Fonteles MC, Greenberg RN, Crytzer J, Monteiro HSA, Currie MG \& Forte LR (1998). Natriuretic and kaliuretic activities of guanylin and uroguanylin in the isolated perfused rat kidney. American J oumal of Physiology, 44: F101-F111.

7. Fan $X$, Wang $Y$, London RM, Eber SL, Krause WJ, Freeman RH \& Forte LR (1997). Signaling pathways for guanylin and uroguanylin in the digestive, renal, central nervous, reproductive, and lymphoid systems. Endocrinology, 138: 46364648.

8. Hamra FK, Eber SL, Chin DT, Currie MG \& Forte LR (1997). Regulation of intestinal uroguanylin/guanylin receptor-mediated responses by mucosal acidity. Proceedings of the National Academy of Sciences, USA, 94: 2705-2710.

9. Carrithers $\mathrm{SL}$, Barber MT, Biswas $\mathrm{S}$, Parkinson SJ, Park PK, Goldstein SD \&
Waldman SA (1996). Guanylyl cyclase C is a selective marker for colorectal tumors in human extraintestinal tissues. Proceedings of the National Academy of Sciences, USA, 93: 14827-14832.

10. Kuhn M, Kulalsiz H, Adermann K, Rechkemmer G \& Forssmann WG (1994). Radioimmunoassay for circulating human guanylin. FEBS Letters, 341: 218-222.

11. Liang P, Averboukh L \& Pardee AB (1993). Distribution and cloning of eukaryotic mRNAs by means of differential display: refinements and optimization. Nucleic Acids Research, 21: 3269-3275.

12. Mann EA, Jump $M L, W u$ J, Yee $E \&$ Giannella RA (1997). Mice lacking the guanylyl cyclase $C$ receptor are resistant to STa-induced intestinal secretion. Biochemical and Biophysical Research Communications, 239: 463-466.

13. London RM, Eber SL, Visweswariah SS, Krause WJ \& Forte LR (1999). Structure and activity of OK-GC: a kidney receptor guanylate cyclase activated by guanylin peptides. American J ournal of Physiology, 276 (Part 2): F882-F891. 